\title{
Hubungan Lalapan dengan Kejadian Infeksi Soil Transmitted Helmiths (STH) pada Anak Sekolah di Kecamatan Gandus Tahun 2019
}

\author{
Hafyarie Harnan', Rico Januar Sitorus ${ }^{2}$, Chairil Anwar ${ }^{3}$, Herry Hermansyah ${ }^{4}$, Hernita ${ }^{5}$ \\ ${ }^{1}$ Mahasiswa S2 Ilmu Kesehatan Masyakarat, Fakultas Kesehatan Masyarakat, Universitas Sriwijaya \\ ${ }^{2}$ Prodi Ilmu Kesehatan Masyakarat, Fakultas Kesehatan Masyarakat, Universitas Sriwijaya \\ ${ }^{3}$ Bagian Parasitologi, Fakultas Kedokteran, Universitas Sriwijaya \\ ${ }^{4}$ Jurusan Analis Kesehatan, Poltekkes Kemenkes Palembang, Indonesia \\ ${ }^{5}$ Analis Kesehatan, Puskesmas Gandus, Palembang
}

\section{Article Info \\ Article history: \\ Received Des 07 $7^{\text {th }}, 2019$ \\ Revised Jan $16^{\text {th }}, 2020$ \\ Accepted Jan $21^{\text {th }}, 2020$}

\section{Keyword:}

STH,

Helminthiasis,

Vegetable,

Faeces,

Gandus,

\begin{abstract}
Soil Transmitted Helmiths (STH) infections are still common in developing countries including Indonesia. This STH infection receives less attention because most are asymptomatic. If this is allowed to continue, the STH infection will become more severe and dangerous. Primary school-age children are prone to this infection. Many factors cause the occurrence of these STH infections. Among the habits of consuming vegetables. This study aims to analyze the relationship between fresh vegetables consumption in school children in Gandus District, Palembang City. Method: This was an observational analytic study with a cross sectional design. The study was conducted on 174 elementary school children spread across five villages. Sampling was done by Multi Stage Random Sampling. Primary data collection was obtained through direct interviews using a questionnaire. Examination of faeces was carried out to identify worm infections using the Kato Katz method and Harada Mori modification. Data were then analyzed using bivariate and multivariate tests using the Stata version 15 application. Research Results: The results of examination of faeces were positive with helminthiasis $23.6 \%$. Bivariate analysis showed that habits before serving fresh vegetables $(p=0.047) ; O R=2,329$ and outside eating habits $(p=0.016) ; O R=2.529$ has a significant relationship to the incidence of STH infection, but the frequency of consuming vegetables $(p=0.493) ; O R=1.297$ and place to buy vegetables $(p=0.318) ; O R=1.43$ has no significant relationship. The most dominant factor is eating vegetables outside the home. The habit before presenting fresh vegetables and the habit of consuming fresh vegetables outside the home are risk factors for STH infection. The most influential risk factor for the incidence of STH infections in the Gandus District of Palembang City is the habit of eating vegetables outside the home.
\end{abstract}

\footnotetext{
ABSTRAK

Infeksi Soil Transmitted Helmiths (STH) masih banyak ditemukan di negara berkembang termasuk Indonesia. Infeksi STH ini kurang mendapatkan perhatian sebab kebanyakan tanpa gejala. Apabila hal tersebut dibiarkan terus menerus maka infeksi STH ini akan menjadi lebih berat dan berbahaya. Anak usia sekolah dasar rentan untuk mengalami infeksi ini. Banyak faktor yang menyebabkan kejadian infeksi STH tersebut. Diantaranya kebiasaan mengkonsumi lalalapan. Penelitian ini bertujuan untuk menganalisis hubungan konsumsi lalapan pada anak sekolah di Kecamatan Gandus Kota Palembang. Metode penelitian ini bersifat analitik observasional dengan rancangan cross sectional. Penelitian dilakukan terhadap 174 anak sekolah dasar yang
} 
tersebar di lima kelurahan. Pengambilan sampel dilakukan secara Multi Stage Random Sampling. Pengumpulan data Primer diperoleh melalui wawancara langsung dengan menggunakan kuesioner. Dilakukan pemeriksaan faeces untuk mengidentifikasi adanya infeksi kecacingan menggunakan metode Kato Katz dan modifikasi Harada Mori. Data selanjutnya dianalisis menggunakan uji bivariate dan multivariate menggunakan aplikasi Stata versi 15. Hasil pemeriksaan faeces didapatkan positif infeksi kecacingan 23,6\%. Analisis bivariat menunjukkan bahwa kebiasaan sebelum menyajikan lalapan $(p=0,047)$; OR=2,329 dan kebiasaan makan lalapan di luar $(\mathrm{p}=0,016)$; $\mathrm{OR}=2,529$ memiliki hubungan yang signifikan terhadap kejadian infeksi STH, akan tetapi frekuensi mengkonsumsi lalapan $(\mathrm{p}=0,493)$; $\mathrm{OR}=1,297$ dan tempat beli lalapan $(\mathrm{p}=0,318) ; \mathrm{OR}=1,43$ memiliki hubungan yang tidak signifikan. Faktor yang paling dominan adalah makan lalapan di luar rumah. Kesimpulan kebiasaan sebelum menyajikan lalapan dan kebiasaan mengkonsumi lalapan di luar rumah merupakan faktor risiko kejadian infeksi STH. Faktor risiko yang paling berpengaruh terhadap kejadian infeksi STH di Kecamatan Gandus Kota Palembang adalah kebiasaan makan lalapan di luar rumah.

Kata Kunci : STH, kecacingan, lalapan, feses, gandus

Copyright (C) Jurnal Analis Medika Bio Sains

\section{Pendahuluan}

Infeksi Soil Transmitted Helmiths (STH) termasuk golongan Neglected Tropical Diseases (NTDs) yang masih belum mendapatkan prioritas di suatu negara, bahkan keadaannya semakin meningkat. Padahal faktanya penyakit tropis ini harus dikendalikan karena menyebar di kalangan orang miskin dan masyarakat pinggiran yang memiliki keterbatasan sumber daya (Wibawa \& Satoto, 2016).

NTDs merupakan penyakit terabaikan yang menyebabkan infeksi paling umum di dunia pada orang yang hidup dalam kemiskinan yang tersebar luas di masyarakat sehingga negara-negara yang terkena dampak tersebut menjadi tidak stabil dan pada akhirnya dapat meningkatkan konflik dan mempengaruhi kebijakan internasional dan luar negeri (Hotez, 2014). NTDs mempengaruhi sekitar satu milyar orang-orang di 149 negara berkembang yang menimbulkan banyak dampak negatif seperti anemia, kebutaan, gangguan kognitif bahkan kematian (Peeling, Boeras, \& Nkengasong, 2017).

Berdasarkan data tahun 2006 untuk jumlah total infeksi cacing ini secara global antara 11\% hingga 16\% dari kasus infeksi STH dunia terjadi di Indonesia dan sebagian besar penduduk Indonesia yakni sekitar 195 juta orang berada di daerah endemik STH (31 dari 33 provinsi Indonesia), termasuk 13 juta anak-anak prasekolah dan 37 juta anak usia sekolah (Tan, Kusriastuti, Savioli, \& Hotez, 2014).

Prevalensi infeksi STH tahun 2018 di Kecamatan Gandus sebesar 29,3\% (Ramayanti, 2019). Untuk itulah peneliti tertarik untuk mendalami lagi prevalensi infeksi STH namun dengan sampel dan jumlah sekolah yang lebih banyak. Selain itu juga masyarakat Indonesia menyukai makan lalapan. Karena lalapan itu sendiri merupakan kumpulan sayuran yang bermanfaat bagi kesehatan. Maraknya warung pecel ayam ataupun warung ayam bakar membuat masyarakat lebih suka dikarenakan tempat tersebut menyajikan lalapan dengan harga yang terjangkau. Sayuran merupakan makanan yang memilki kandungan gizi tinggi yang mengandung protein, vitamin, mineral dan mikronutrien lainnya yang penting bagi tubuh (Santoso, 2011). Namun dalam beberapa penelitian mengungkapkan bahwa lalapan merupakan salah satu faktor untuk terjadinya kejadian infeksi STH. Hal tersebut didukung dengan berbagai penelitian yang mengidentifikasi adanya telur cacing dalam lalapan seperti pada lalapan mentah pada warung pecel lele di Bandar Lampung (Wantini \& Sulistianingsih, 2019), 
warung penyetan pujasera simpang lima Semarang (Alfiani, Sulistyani, \& Ginandjar, 2018) dan warung makan pada Kecamatan Seberang Ulu 2 Palembang (Prameswarie, Chairil, \& Prameswari, 2019). Hal tersebut didukung juga dengan cara pengolahan lalapan kurang baik yang berisiko terhadap kesehatan dikarenakan terjadi penularan infeksi ke manusia (Balarak et al., 2016).

Penelitian ini bertujuan untuk menganalisis hubungan antara kebiasaan makan lalapan pada anak sekolah dengan kejadian infeksi STH di Kecamatan Gandus yang merupakan salah satu Kecamatan di Kota Palembang.

\section{Metode Penelitian}

Jenis penelitian ini adalah penelitian observasional analitik dengan menggunakan rancangan studi crosssectional. Penelitian dilaksanakan di Kecamatan Gandus Kota Palembang Provinsi Sumatera Selatan dengan sampel siswa Sekolah Dasar (SD) dan Madrasah Ibtidaiyah (MI) yang berasal dari 5 kelurahan, yaitu Kelurahan Gandus, Kelurahan Pulokerto, Kelurahan Karang Jaya, Kelurahan Karang Anyar dan Kelurahan 36 Ilir. Sampel berjumlah 174 yang diambil dengan cara multistage random sampling.

Dilakukan pemeriksaan feses untuk mengetahui adanya infeksi kecacingan menggunakan teknik Kato Katz dan modifikasi Harada Mori. Data karateristik responden serta kebiasaan memakan lalapan diambil menggunakan kuesioner yang berjumlah sepuluh pertanyaan. Data konsumsi lalapan meliputi frekuensi makan lalapan, tempat beli lalapan, pengolahan lalapan sebelum dihidangkan dan frekuensi makan lalapan di luar rumah. Analisis data dilakukan menggunakan program Stata versi 15 meliputi univariate dan bivariate. Analisis bivariate menggunakan uji chi-square karena dalam penelitian ini menguji hubungan atau pengaruh dua variabel pada tingkat kemaknaan $95 \%(\alpha=0,05)$.

\section{Hasil Penelitian dan Pembahasan}

Berdasarkan data distribusi karakteristik responden (Tabel 1) jumlah subyek penelitian untuk jenis kelamin adalah sama yaitu 87 responden baik laki-laki maupun perempuan. Proporsi kelas pada responden yang paling banyak adalah proporsi pada Kelas 1 yaitu sebanyak 37 anak (21,26\%). Untuk proporsi umur yang paling banyak adalah pada kelompok umur 8 tahun yaitu 32 anak $(18,39 \%)$.

Tabel 1.Karakteristik Responden $(n=174)$

\begin{tabular}{lcr}
\hline \multirow{2}{*}{ Karakteristik Responden } & \multicolumn{2}{c}{ Frekuensi } \\
\cline { 2 - 3 } & $\mathrm{n}$ & $\%$ \\
\hline Jenis Kelamin & & \\
Laki-laki & 87 & 50,00 \\
Perempuan & 87 & 50,00 \\
& & \\
Kelas & & \\
1 & 37 & 21,26 \\
2 & 28 & 16,09 \\
3 & 21 & 12,07 \\
4 & 25 & 14,37 \\
5 & 29 & 16,67 \\
6 & 34 & 19,54
\end{tabular}




\begin{tabular}{lcr} 
Umur (tahun) & & \\
6 & 18 & 10,34 \\
7 & 31 & 17,82 \\
8 & 32 & 18,39 \\
9 & 20 & 11,49 \\
10 & 31 & 17,82 \\
11 & 28 & 16,09 \\
12 & 9 & 5,17 \\
13 & 3 & 1,72 \\
14 & 2 & 1,15 \\
\hline
\end{tabular}

Sumber : Data primer 2019

Distribusi frekuensi variabel dependen dan independen menunjukan bahwa proporsi anak yang mengalami kejadian infeksi STH sebanyak 42 anak (23,56\%), proporsi frekuensi sering makan lalapan di rumah sebanyak 111 responden (63,79\%), proporsi tempat membeli lalapan di pasar sebanyak 90 responden $(51,7 \%)$, proporsi kebiasaan sebelum menyajikan lalapan dicuci pada air yang tidak mengalir sebanyak 118 responden (67,8\%) dan kebiasaan sering makan lalapan di luar rumah sebanyak 99 responden (56,9\%).

Salah satu faktor risiko yang menyebabkan terjadinya infeksi STH pada usia anak Sekolah Dasar adalah mengkonsumsi sayuran mentah yaitu lalapan yang juga didukung dengan latar belakang sosial ekonomi yang rendah (Anuar, Salleh, \& Moktar, 2014). Hasil penelitian ini menunjukkan proporsi kejadian infeksi STH pada anak sekolah SD dan MI di Kecamatan Gandus sebanyak 41 anak (23,56\%), yang sebagian besar sering mengkonsumi lalapan yaitu lebih dari sekali dalam seminggu sebesar 28 anak (25,2\%). Hasil analisis bivariat tentang hubungan frekuensi makan lalapan di rumah dengan kejadian infeksi STH (Tabel 2), didapatkan nilai $p$-value $=0,493$ maka hubungan yang terjadi adalah tidak signifikan. Yang termasuk frekuensi sering adalah lebih dari sekali dalam seminggu anak tersebut makan lalapan di rumah dan sebaliknya frekuensi jarang adalah hanya seminggu sekali bahkan tidak pernah makan lalapan.

Tabel 2. Hubungan Frekuensi Makan Lalapan di rumah dengan Kejadian Infeksi STH.

\begin{tabular}{|c|c|c|c|c|c|c|c|}
\hline \multirow{3}{*}{$\begin{array}{l}\text { Frekuensi Makan } \\
\text { Lalapan di rumah }\end{array}$} & \multicolumn{4}{|c|}{ Infeksi STH } & \multirow{3}{*}{$p$ value } & \multirow{3}{*}{ OR } & \multirow{3}{*}{$95 \% \mathrm{CI}$} \\
\hline & \multicolumn{2}{|c|}{ Positif } & \multicolumn{2}{|c|}{ Negatif } & & & \\
\hline & $\mathrm{n}$ & $\%$ & $\mathrm{n}$ & $\%$ & & & \\
\hline Sering & 28 & 25,2 & 83 & 74,8 & \multirow[t]{3}{*}{0,493} & \multirow[t]{3}{*}{1,297} & \multirow[t]{3}{*}{$0,58-2,99$} \\
\hline Jarang & 13 & 20,6 & 50 & 79,4 & & & \\
\hline Total & 41 & 23,6 & 133 & 76,4 & & & \\
\hline
\end{tabular}

Secara umum terdapat dua cara masuknya nematoda usus dalam menginfeksi tubuh manusia, yaitu melalui mulut dan kulit. Telur-telur tersebut dapat masuk ke dalam tubuh manusia, diantaranya melalui tidak bersih dalam mencuci, sayuran yang tidak dimasak sedangkan dari larva nematoda usus dapat dimungkinkan melalui air yang terkontaminasi (Gillespie \& Pearson, 2001). Penularan kepada hospes baru tergantung kepada tertelannya telur matang yang infektif atau larva, atau menembusnnya larva ke dalam kulit atau selaput lendir. Seringkali larva di dalam telur ikut tertelan dengan makanan (Brown, 1997). Kontaminasi telur STH pada lalapan juga bisa dipengaruhi oleh proses penyimpanan lalapan sebelum diolah. Lalapan yang berada di warung-warung makan ada yang disimpan di lemari pendingin dan ada juga yang tidak. Pedagang yang tidak menyimpan sayuran di lemari pendingin biasanya hanya meletakkan sayuran di dapur atau di keranjang sayur yang belum diketahui kebersihannya. Bila tempat penyimpanan sayuran tidak bersih dan lembab, 
memungkinkan untuk telur Soil Transmitted Helminths (STH) bertahan dan berkembang (Wardhana, Kurniawan, \& Mustofa, 2014). Dalam berbagai penelitian bahwa banyak terdapat identifikasi telur cacing pada lalapan baik yang dijual di pasar tradisional maupun pasar modern bahkan supermarket. Kontaminasi telur cacing nematoda usus pada sayur kubis di pasar tradisional sebanyak $22 \%$ sedangkan yang tidak terkontaminasi sebanyak 78\% lebih besar daripada di kontaminasi warung makan yaitu sebanyak 11\% dan yang tidak terkontaminasi 89\% (Anggraini \& Kristiawan, 2018). Selaras dalam penelitian ini bahwa kejadian infeksi STH paling banyak yaitu pada responden yang membeli lalapan di pasar sebanyak 24 orang $(26,67 \%)$ dan yang membeli di warung sebanyak 17 orang (20,24\%). Namun hasil analisis bivariat tentang hubungan antara tempat beli lalapan dengan kejadian infeksi STH (Tabel 3), didapatkan nilai $p$ value $=0,318$ maka hubungan yang terjadi adalah tidak signifikan.

Tabel 3. Hubungan antara tempat beli lalapan dengan kejadian infeksi STH

\begin{tabular}{|c|c|c|c|c|c|c|c|}
\hline \multirow{3}{*}{ Tempat beli lalapan } & \multicolumn{4}{|c|}{ Infeksi STH } & \multirow{3}{*}{$p$ value } & \multirow{3}{*}{ OR } & \multirow{3}{*}{$95 \% \mathrm{CI}$} \\
\hline & \multicolumn{2}{|c|}{ Positif } & \multicolumn{2}{|c|}{ Negatif } & & & \\
\hline & $\mathrm{n}$ & $\%$ & $\mathrm{n}$ & $\%$ & & & \\
\hline Pasar & 24 & 26,67 & 66 & 73,33 & 0,318 & 1,43 & $0,667-3,118$ \\
\hline Warung & 17 & 20,24 & 67 & 79,76 & & & \\
\hline Total & 41 & 23,56 & 133 & 76,44 & & & \\
\hline
\end{tabular}

Lalapan yang terkontaminasi juga berperan dalam kejadian infeksi STH. Kontaminasi yang terjadi pada lalapan dapat terjadi pada proses produksi, pengumpulan, transportasi, persiapan atau selama pengolahan. Bagian terpenting dalam pengolahan adalah pencucian (Mutiara, 2015). Ada beberapa faktor yang berpengaruh terhadap kebersihan pengolahan dan pemanfaatan sayuran yang dikonsumsi oleh manusia, seperti cara mencuci sayuran dan teknik mencuci, merupakan hal yang perlu diperhatikan. Penggunaan air mengalir lebih dianjurkan daripada menggunakan air yang diam (menggenang), seperti air dalam wadah/ bak air yang digunakan untuk mencuci sayuran secara berulang. Hal ini dapat berpengaruh terhadap risiko pencemaran oleh berbagai jenis bahan pencemar seperti pestisida baik organik maupun anorganik (Nugroho, Djannah, \& Mulasari, 2010). Dalam penelitian ini menyebutkan bahwa yang mengalami kejadian infeksi STH sebagian besar mempunyai kebiasaan sebelum menyajikan lalapan dibersihkan dengan air yang tidak mengalir yaitu dibersihkan di dalam ember atau wadah sebesar 27,97\%. Sedangkan yang mencuci pada air mengalir namun mengalami kejadian infeksi STH sebesar 14,29\%. Hasil analis (Tabel 4) menunjukkan adanya hubungan yang signifikan antara perilaku kebiasaan mencuci lalapan dengan terjadinya kejadian infeksi STH ( $p$-value $=0,047)$ dengan OR = 2,329 yang artinya kebiasaan mencuci lalapan pada air yang tidak mengalir seperti di dalam wadah atau baskom mempunyai peluang untuk mengalami kejadian infeksi STH sebesar 2,329 kali dibandingkan dengan mencuci lalapan pada air yang mengalir. Teknik pencucian sayuran yang benar adalah sayuran dicuci pada air kran yang mengalir, dicuci lembar perlembar, kemudian dicelupkan sebentar ke dalam air panas atau dibilas dengan menggunakan air matang sehingga STH yang mungkin melekat dapat terbuang bersama aliran air tersebut (Direktorat Jenderal \& RI, 2010). 
ISSN: 2656-2456 (Online)

ISSN: 2356-4075 (Print)

Tabel 4. Hubungan antara kebiasaan sebelum menyajikan lalapan dengan kejadian infeksi STH

\begin{tabular}{|c|c|c|c|c|c|c|c|}
\hline \multirow{3}{*}{$\begin{array}{l}\text { Kebiasaan sebelum } \\
\text { menyajikan lalapan }\end{array}$} & \multicolumn{4}{|c|}{ Infeksi STH } & \multirow{3}{*}{$p$ value } & \multirow{3}{*}{ OR } & \multirow{3}{*}{$95 \% \mathrm{CI}$} \\
\hline & \multicolumn{2}{|c|}{ Positif } & \multicolumn{2}{|c|}{ Negatif } & & & \\
\hline & $\mathrm{n}$ & $\%$ & $\mathrm{n}$ & $\%$ & & & \\
\hline $\begin{array}{l}\text { Dicuci pada air tidak } \\
\text { mengalir }\end{array}$ & 33 & 27,97 & 85 & 72,03 & 0,047 & 2,329 & $0,951-6,290$ \\
\hline $\begin{array}{l}\text { Dicuci pada air } \\
\text { mengalir }\end{array}$ & 8 & 14,29 & 48 & 85,71 & & & \\
\hline Total & 41 & 23,56 & 133 & 76,44 & & & \\
\hline
\end{tabular}

Hasil analisis bivariat tentang hubungan antara kebiasaan makan lalapan di luar rumah seperti makan di warung pecel lele, ayam bakar dan sebagainya dengan kejadian infeksi STH (Tabel 5), didapatkan nilai $p$ value $=0,016$ maka hubungan yang terjadi adalah signifikan dengan $\mathrm{OR}=2,529$ yang artinya kebiasaan sering yaitu lebih dari sekali dalam seminggu makan lalapan di luar rumah maka berpeluang 2,529 kali mengalami kejadian infeksi STH dibandingkan yang jarang yaitu yang hanya seminggu sekali bahkan kurang untuk makan lalapan di luar rumah

Tabel 5. Hubungan antara kebiasaan makan lalapan di luar dengan kejadian infeksi STH

\begin{tabular}{lccccccc}
\hline \multirow{2}{*}{$\begin{array}{c}\text { Kebiasaan makan } \\
\text { lalapan di luar rumah }\end{array}$} & \multicolumn{9}{c}{ Infeksi STH } & & \multirow{2}{*}{ Positif } & \multicolumn{2}{c}{ Negatif } & \multirow{2}{*}{$p$ value } & OR & \multirow{2}{*}{ 95\%CI } \\
\cline { 2 - 6 } & $\mathrm{n}$ & $\%$ & $\mathrm{n}$ & $\%$ & & & \\
\hline Sering & 30 & 30,30 & 69 & 69,70 & 0,016 & 2,529 & $1,114-6,049$ \\
\hline Jarang & 11 & 14,67 & 64 & 85,33 & & & \\
\hline Total & 41 & 23,56 & 133 & 76,44 & & & \\
\hline
\end{tabular}

Maraknya keberadaan warung makan di luar yang menyajikan menu tambahan berupa lalapan juga berperan dalam terjadinya kejadian infeksi STH pada penelitian ini. Namun dengan seringnya mengkonsumsi lalapan di luar maka akan berpeluang untuk mengalami infeksi STH seperti di dalam penelitian ini yang menyebutkan terdapat hubungan yang signifikan antara kebiasaan makan lalapan di luar seperti warung makan, pecel lele, ayam bakar dan sebagainya dengan kejadian infeksi STH ( $p$-value $=0,016)$ dengan OR $=2,529$ yang artinya sering makan lalapan di luar yaitu lebih dari sekali dalam tiap minggu mempunyai peluang untuk mengalami kejadian infeksi STH sebesar 2,529 kali dibandingkan yang jarang yaitu hanya sekali dalam seminggu atau bahkan kurang untuk lalapan di luar. Hal ini sejalan dengan berbagai penelitian yang mengidentifikasi keberadaan telur cacing pada lalapan yang disajikan di warung makan, pecel lele, ayam bakar dan sebagainya seperti pada warung ikan bakar di Kota Palu (Widjaja, Lobo, Oktaviani, \& Puryadi, 2014), warung makan kaki lima di Bandar Lampung (SAFITRI, 2018) dan warung makan di Kota Palembang (TONI, 2018).

Analisis multivariate menggunakan uji regresi logistik. Pada penelitian ini nilai $p$-value $<0,25$ pada analisis bivariate disertakan dalam analisis multivariate, terdapat dua variable yaitu kebiasaan sebelum menyajikan lalapan $(p$-value $=0,047)$ dan kebiasaan makan lalapan di luar rumah $(p$-value $=0,016)$. Hasil analisis multivariate tentang hubungan kebiasaan sebelum menyajikan lalapan dengan kejadian infeksi STH didapatkan nilai $p$-value $=0,053$ maka hubungan yang terjadi adalah tidak signifikan. Sedangkan hubungan kebiasaan sering makan lalapan di luar dengan kejadian infeksi STH didapatkan nilai $p$-value =0,019 maka hubungan yang terjadi adalah signifikan dengan $\mathrm{OR}=2,541$ yang artinya bahwa anak yang mempunyai 
kebiasaan sering yaitu lebih dari sekali dalam seminggu makan lalapan di luar rumah seperti warung pecel lele, ayam bakar dan sebagainya, maka berpeluang 2,541 kali untuk mengalami kejadian infeksi STH dibandingkan dengan yang jarang yaitu hanya seminggu sekali bahkan kurang.

\section{Kesimpulan}

Lalapan merupakan media yang berperan dalam terjadinya kejadian infeksi STH pada anak SD/MI di Kecamatan Gandus Kota Palembang. Termasuk juga yang berperan dalam terjadinya kejadian infeksi STH adalah personal hygiene yang kurang baik dari pedagang warung makan, pedagang sayur, pedagang pasar maupun masyarakat selaku konsumen lalapan.

\section{Daftar Pustaka}

Alfiani, U., Sulistyani, S., \& Ginandjar, P. (2018). Hubungan Higiene Personal Pedagang dan Sanitasi Makanan dengan Keberadaan Telur Cacing Soil Transmitted Helminths (STH) pada Lalapan Penyerta di Pujasera Simpanglima Kota Semarang. Jurnal Kesehatan Masyarakat (e-Journal), 6(1), 685-695.

Anggraini, D. A., \& Kristiawan, A. (2018). Identifikasi Telur Nematoda Usus pada Sayuran Kubis (Brassica oleracea) di Pasar Tradisional, Supermarket, dan Warung Makan Gresik Tahun 2018. Jurnal Sains, $8(16)$.

Anuar, T. S., Salleh, F. M., \& Moktar, N. (2014). Soil-transmitted helminth infections and associated risk factors in three Orang Asli tribes in Peninsular Malaysia. Scientific reports, 4, 4101.

Balarak, D., Ebrahimi, M., Modrek, M. J., Bazrafshan, E., Mahvi, A. H., \& Mahdavi, Y. (2016). Investigation of parasitic contaminations of vegetables sold in markets in the city of Tabriz in 2014. Glob J Health Sci, 8(10), 178-184.

Brown, H. (1997). Dasar Parasitologi Klinis. Edisi ke-3: Jakarta: Gramedia.

Direktorat Jenderal, P., \& RI, P. K. K. (2010). Kumpulan Modul Kursus Hygiene Sanitasi Makanan \& Minuman: Jakarta: Depkes RI.

Gillespie, S. H., \& Pearson, R. D. (2001). Principles and practice of clinical parasitology: Wiley Online Library.

Hotez, P. J. (2014). Ten global "hotspots” for the neglected tropical diseases: Public Library of Science.

Mutiara, H. (2015). Identifikasi kontaminasi telur soil transmitted helminths pada makanan berbahan sayuran mentah yang dijajakan kantin sekitar kampus Universitas Lampung Bandar Lampung. Juke Unila, $5(9), 28-32$.

Nugroho, C., Djannah, S. N., \& Mulasari, S. A. (2010). Identifikasi kontaminasi telur nematoda usus pada sayuran kubis (Brassica oleracea) warung makan lesehan Wonosari Gunungkidul Yogyakarta tahun 2010. Jurnal Kesehatan Masyarakat, 4(1), 67-75.

Peeling, R. W., Boeras, D. I., \& Nkengasong, J. (2017). Re-imagining the future of diagnosis of Neglected Tropical Diseases. Computational and structural biotechnology journal, 15, 271-274.

Prameswarie, T., Chairil, A. G., \& Prameswari, M. (2019). Dua Spesies Cacing Soil Transmitted Helminths pada Sayuran Selada (Lactuca sativa) yang dijual di Warung Makan pada Kecamatan Seberang Ulu II Palembang. SRIWIJAYA JOURNAL OF MEDICINE, 2(3), 159-163. 
Ramayanti, I. (2019). Prevalensi Infeksi Soil Transmitted Helminths pada Siswa Madrasah Ibtidaiyah Ittihadiyah Kecamatan Gandus Kota Palembang. Syifa'MEDIKA: Jurnal Kedokteran dan Kesehatan, $8(2), 102-107$.

Safitri, R. (2018). Identifikasi Kontaminasi Telur Soil Transmitted Helminths (STH) pada Lalapan Kubis (Brassica oleracea) di Warung Makan Kaki Lima Sepanjang Jalan Zainal Abidin Pagar Alam, Kota Bandar Lampung.

Santoso, I. A. (2011). Serat pangan (dietary fiber) dan manfaatnya bagi kesehatan. Magistra, 23(75), 35.

Tan, M., Kusriastuti, R., Savioli, L., \& Hotez, P. J. (2014). Indonesia: an emerging market economy beset by neglected tropical diseases (NTDs): Public Library of Science.

Toni, M. O. E. (2018). Identifikasi Kontaminasi Telur Cacing Usus (Soil Transmited Helminths) pada Lalapan Kemangi (Ocimum bacilicum) di Warung Makan Kecamatan Seberang Ulu 2 Kota Palembang Tahun 2018. Universitas Muhammadiyah Palembang.

Wantini, S., \& Sulistianingsih, E. (2019). Hubungan Higiene Sanitasi Terhadap Telur Nematoda Usus Pada Lalapan Mentah di Warung Pecel Lele Sepanjang Jalan ZA Pagar Alam Bandar Lampung. Jurnal Analis Kesehatan, 8(1), 1-6.

Wardhana, K., Kurniawan, B., \& Mustofa, S. (2014). Identification of Soil Transmitted Helminths Egg on Fresh Cabbage (Brassica oleracea) at Lampung University Food Stalls. Jurnal Kedoteran Unila, 8695.

Wibawa, T., \& Satoto, T. B. T. (2016). Magnitude of Neglected tropical diseases in Indonesia at Postmillennium development goals era. Journal of tropical medicine, 2016.

Widjaja, J., Lobo, L. T., Oktaviani, O., \& Puryadi, P. (2014). Prevalensi dan jenis telur cacing soil transmitted helmints (STH) pada sayuran kemangi pedagang ikan bakar di Kota Palu. Jurnal Buski, 5(2). 